\section{Influence of Iproniazid Pretreatment on Forma- tion of Gastric Ulcers by Reserpine in the Rat}

Reserpine, besides its effects on the central nervous and cardiovascular system, has an important influence on the gastro-intestinal tract. This drug stimulates gastric sccretion and motility ${ }^{1-6}$ and increases the production of gastric hemorrhagic erosions after ligation of the pylorus in rats 7,8 . It has been demonstrated that this substance releases serotonin from the brain and intestines ${ }^{2,10}$. The central nervous effects of reserpine are markedly changed after pretreatment with iproniazid, an inhibitor of monoamine oxidase, which prevents the decreases of serotonin in the brain by reserpine 11,12 . This suggests that the central pharmacological actions of reserpine might be due at least partly to alterations in the monoamine metabolism in the brain ${ }^{13}$.

The study of the influence of pretreatment with iproniazid (MarsilidR) on the gastro-intestinal effects of reserpine might give additional informations on the working mechanism of reserpine.

In a first series of experiments, the possible inhibitory influence of iproniazid pretreatment on the production of gastric erosions in the Shay-rat preparation was examined. 60 rats were divided in 3 groups. One group served as a control, a second group received $5 \mathrm{mg} / \mathrm{kg}$ reserpine intraperitoneally at the time of the ligation of the pylorus, and the third group was injected with iproniazid $(100 \mathrm{mg} / \mathrm{kg}$ intraperitoneally $5 \mathrm{~h}$ before ligation of the pylorus) and reserpine $(5 \mathrm{mg} / \mathrm{kg}$ at the time of pyloric ligation). Ligation of the pylorus was performed under light ether anesthesia. At least $48 \mathrm{~h}$ prior to operation all food had been removed. Water was withheld from the time of operation until sacrifice. $71 / 2$ h after the pylorus ligation, the rats were killed, their stomach removed, the accumulated gastric juice collected, and the gastric mucosa examined for ulcers or erosions.

The results show that iproniazid markedly inhibits the production of gastric hemorrhagic erosions by reserpine. Indeed, while all the animals which had received reserpine alone, showed hemorrhagic erosions of tho glandular part of the stomach [antrum and (or) corpus] $7 \frac{1}{2} \mathrm{~h}$ after pyloric ligation, no such lesions were observed in the reserpine animals which had been pretreated with iproniazid. The rats of the control group also did not show gastric erosions after the same time interval.

1 M, L. Clark and E. M. SCHNeIder, (iastrocnterology 29, 877 (1955).

2 B. J. Haverback, T. D. Stevenson, A. Sjoerdsma, and I.. L. TERRY, Amer. J med, Sci, 230,601 (1955).

3 A. J. Plummer, A. T.. Earl, J. A. Scingelder, J. Trapold, and W. E. BARret, Ann. N. Y. Acad. Sci. $59,8(1954)$.

4 E. W. Barrett, R. A. Rutledge, and B. Rogie, Fed. Proc, 13 , 334 (1954).

5 W. E. Barret, A. J. Plummer, E. A. Earl, and B. Rogte, J. Pharmacol. 113,3 (1955).

6 J. La Barre and Ch. Lieber, C. R. Soc. Biol., Paris 151, 1.11! (1957).

7 J. LA Barre and J. J. Desmarez, C. R. Soc. Biol, Paris 15t, $1451(1957)$.

I. LeUSEN and E. LACrolx, Arch. int. Pharmacodyn., in press (1958).

- A. Pletscher, P. A. Siore, and 3. B. Brodie, Science 12z, 374 (1955).

${ }^{10}$ B. B. Brodie, A. Puetscuyre, and P. A. Snore, Science 122, $968(1955)$

t3 H. Besendorf and A. Pletscher, Helv. plyysiol, pharmacol. Acta 14,383 (1956).

12 A. Pletscher, Exper. 12,479 (1956).

13 P. A. Shore, J. A. R. Mead, R. G. Kuntzman, S. Spector, and B. B. Brodie, Science $126,1063(1957)$.
The mean values of the $\mathrm{pH}$, free acidity, and total volume of the collected gastric juice showed no significant difference between the reserpine group and the iproniazidreserpine groups.

It has been found that the serotonin precursor 5-hydroxytryptophan inhibits gastric acid secretion ${ }^{14}$. Yet, consistently lesions of the glandular portion of the gastric mucosa were found in rats after a single injection of a high amount of this substance ${ }^{15}$. Reserpine on the other hand, which decreases and liberates the serotonin in the gastro-intestinal tract, increases gastric acid secretion and ulcer formation. Iproniazid, which is known to interfere with the metabolism of the monomines inhibits the production of gastric erosions by reserpine. The possibility exists that this protective effect depends on the interference of this substance with serotonin metabolism.

I. J JUSEN, E. LACROIX, and G. DEnJESTt:R

Labovatory of Physio-Pathology of the University of Ghent, October 9, 195s'.

\section{$R e s$ sinte}

Chez le rat à pylore lié, la réserpine $(5 \mathrm{mg} / \mathrm{kg}$ ) provoque l'apparition précoce d'ulcérations gastriques. Ce phénomène fait defaut si les rats ont été traités préalablement par l'jproniazide, un inhibiteur de la monoamino-oxydase.

14 ]3. J. Ilaverback, D. W. Hotidanski, and C. A. M. Hognen, Gastrocinterology 34,188 (1958).

is 13. J. Hayerback and D, li, Bognanski, Proc. Soc, exp. Biol. Meti., N. Y. $05,3192(1957)$.

\section{Kompetitiver Antagonismus zwischen g-Strophanthin und Corticosteron an isolierten Streifen von Rattenaorten*}

Uber eine antagonistische Wirkung von DOC-Glycosid gegenüber Azetylcholin am liroschherzen berichtete Gross ${ }^{1}$. HAEFLL ${ }^{2}$ wies am Froschrectus eine Hemmung der $A$ cetylcholin-Veratrin- und Guanidinkontraktur durch verschiedene Nebennierensteroide, Progesteron und Androgene nach. Wir fanden, dass $B O C$, Corticosteron und Testosteron die durch Serotonin ausgelöste Kontraktion der Rattenaorta hemmen. Alle diese IEffekte sind insofern unspezifischer Natur, als offenbar ganz beliebige Reizstoffe (bzw. Hemmstoffe) durch Steroidhormone antagonisiert werden. Jü̈̈rzlich zeigte l.kONARD ${ }^{3}$, dasss IOOC und Progesteron sogar die elektrisch nusgelöste Kontraktion von Kaninchenkarotiden hemmen.

g-Strophanthin erzeugt in hoher Konzentration $\left(10^{-4}\right.$ $\mathrm{g} / \mathrm{ml})$ an Aortenstreifen von latten cinen langamen Tonusanstieg. Wir fanden, dass dieser lonusanstieg durch Corticosteron gehemmt wird. Es stellte sich die Frage, ob es sich auch hierbei um einen unspezifischen leffekt handelt oder $\mathrm{ob}$, wie sich aus der chemischen Verwand tschaft der Substanzen vermuten laisst, ein echter Antagonismus vorliegt. Zur Klairung dieser lirage wurde versucht, dic Kinetik der Hemmung zu analysieren.

Thoraxaorten von latten wurden etwa 15 h bei $4^{\circ} \mathrm{C}$ aufbewaht, in spiralige Streifen (liurcisgott und BHADRAKOM ${ }^{4}$ von $1-1,5 \mathrm{~mm}$ Breite geschnitten und in einer

* Dieso" Arbeit wurde crmöglicht durch ein Stipendium der "Stiftume der CIBA fur naturwissenschaftiche, medizinische und technische lorschlung

1 l. Gross, lixper, 2, 191 (1916i).

2 H. Hawed, Inamg. Diss, Batiel (19t5)

3 L. J,owskn, Amer. J. Physiol. 189,185 (1957)

4 R. F. lunchoote und S. Bundrakom, J. I'Jarm, exp. Ther. $108,129(1053)$. 